\title{
Histological and miRNAs postmortem changes in incisional wound
}

\author{
Samah F. Ibrahim ${ }^{1,2^{*}}$, Mona M. Ali ${ }^{1}$, Hoda Basyouni ${ }^{1}$, Laila A. Rashed ${ }^{3}$, Eman A. E. Amer ${ }^{4}$ and Dalia Abd El-Kareem ${ }^{5}$
}

\begin{abstract}
Background: Regarding postmortem estimation, the evaluation of early histological and miRNA molecular changes have been of great concerns among forensic scientists due to uncertainty of known conventional methods. The histological and miRNA molecular changes in incisional wound remain poorly described.

Purpose: This evaluation presents a histo-molecular approach that could be used to estimate the early post mortem interval in incisional wound.

Methods: The histological and miRNA (205 and 21) changes were evaluated in 18 female albino rats with incisional wound at three interval times: 0, 24, and $48 \mathrm{~h}$ after infliction.

Results: The wound margin showed progressive morphological changes with increasing postmortem interval. Inflammatory phase had appeared immediately after infliction. After this period, degenerative changes began. mRNA-205 and 21 expressions, detected via real-time PCR, were increased significantly to reach their higher levels at $24 \mathrm{~h}$ after wound infliction, then they were significantly diminished with increasing postmortem interval.
\end{abstract}

Conclusions: Our results suggest that histological and miRNA-205 and miRNA-21 changes, occurred at perimortal incisional wound, could be helpful in forensic work regarding postmortem estimation.

Keywords: Forensic sciences, Perimortal incision, Histological examination, miRNA-205 and miRNA-21, Postmortem interval

\section{Highlights}

- Perimortal incisional wound had been evaluated using histological and bio-molecular techniques in animal study.

- Histological examination revealed early inflammatory phase

- Micro RNA-21 and 205 appeared to be stably expressed and presented up to 2 days postmortem.

- MiRNAs degraded but did not show time dependent manner.

\footnotetext{
* Correspondence: samahibraheem@yahoo.com

${ }^{1}$ Forensic medicine and clinical toxicology, Faculty of Medicine, Cairo University, Cairo, Egypt

${ }_{2}^{2}$ Princess Nourah Bint-Abdulrahman University, Riyadh, Saudi Arabia Full list of author information is available at the end of the article
}

\section{Background}

Wound has been defined as a disruption of the continuity of a tissue structure due to application of mechanical force (Saukko Pekka 2004).

Incisional wounds have been and will remain a major cause of violent death. The nature of the wound, as ante-mortem or postmortem, have to be ascertained by the forensic pathologist (Karlsson 1998; Siddiqui et al. 2016).

Determination of wound vitality in perimortal injuries, and the interpretation of the chronological sequence of events is an important part in forensic work (Obac et al. 2011).

Ante-mortem wound shows tissue reaction and consists essentially of an acute inflammation. Accordingly, many biochemical molecules (e.g., miRNAs) and cells (e.g., neutrophil and mononuclear cell) are involved in this inflammatory process (Vinay et al. 2017). 
MicroRNAs (miRNAs) are small 21- to 25-bp noncoding single-stranded RNA molecules. They play a critical role in all biological processes (Carthew and Sontheimer 2009). MiR-205 is highly expressed in normal skin, while miRNA-21 is induced after skin injury and promotes wound healing (Long et al. 2018; Yi et al. 2008).

Nature of the wound could be estimated via many gross and microscopic changes. Because of the uncertain and variable results of the gross examination, it is important to study the wound using histological (Vinay et al. 2017) and bio-molecular techniques, e.g., miRNA (Da Silva et al. 2016).

Hence, we aimed to evaluate the effect of postmortem interval on cutaneous incisional wound using histological examination and miRNA-205 and miRNA-21 expressions.

\section{Materials and methods}

Prior to conducting this experiment, the study protocol was approved by the Ethical Committee of King Saud University, the institutional animal care and use committee, King Saud University.

This study was conducted on 18 female albino rats with incisional wound.

\section{Experimental incisional wound}

Intraperitoneal thiopental sodium injection $(0.5 \mu \mathrm{g} / \mathrm{g})$ was used to anesthetize the rats. An incision $4 \mathrm{~cm}$ length was made using a surgical blade (no. 15) through the entire thickness of the skin of the thigh.

The animals were sacrificed immediately by cervical dislocation and randomly divided into three groups $(n=6)$ : group I where skin samples were assessed immediately after death, group II where skin samples were assessed 24 hours after death, and group III where skin samples were assessed 48 hours after death. The wounds were left undressed, and rats were kept in their cages at $4{ }^{\circ} \mathrm{C}$ for 2 days.

\section{Histological examination}

Skin samples involving wound margin were collected from animals at previously mentioned durations. For histological examination, each processed specimen was fixed in $10 \%$ formalin, embedded in paraffin blocks, sectioned into $5 \mu \mathrm{m}$ thickness sections on glass slides, and stained with hematoxylin-eosin. Each slide was examined to detect the degree of inflammatory cellular infiltration, edema, hemosiderin deposition, fibrous tissue, and collagen deposition.

\section{Tissue processing and detection of miRNA expression}

The expressions of miRNA were detected at 0,24 , and 48 postmortem hours. An area of approximately $20 \mathrm{mg}$ was excised from the sample's margin at the designed time and immediately frozen in lysis buffer with mercaptopurine. Measuring the miRNA expressions required the following steps, according to Lin et al. (Lin et al. 2013), Wang et al. (Wang et al. 2012), and Wang et al. (Wang et al. 2016).

\section{RNA preparation from skin specimens}

Total RNA was isolated using the mirVana PARIS kit (Ambion, Austin, TX, USA) according to the manufacturer's recommendations.

The average levels of miR-205 and miR-21 expression were normalized relative to the average amounts of U6 snRNAm (internal gene with the similar efficiency of miRNA), using the $2^{-\Delta \Delta C T}$ method (Wang et al. 2016). RNA quality was determined by spectrophotometric analysis (UItrospec 4300 pro, Biochrom, Cambridge, UK).

2. Quantitative reverse transcription-polymerase chain reaction (RT-qPCR).

The reverse transcription reaction was carried out as previously described (Wang et al. 2012) in a total reaction volume of $7.5 \mathrm{~mL}$ using the TaqMan MicroRNA Reverse Transcription Kit (Applied Biosystems, USA) according to the manufacturer's instructions. Quantitative polymerase chain reaction (qPCR) was performed using TaqMan Universal PCR Master Mix (Applied Biosystems) in an ABI 7500 Real-Time PCR system (Applied Biosystems) in triplicate with the following conditions: $95^{\circ} \mathrm{C}$ for $10 \mathrm{~min}$, followed by 40 cycles of $95^{\circ} \mathrm{C}$ for $15 \mathrm{~s}$ and $60^{\circ} \mathrm{C}$ for $1 \mathrm{~min}$. SDS 2.0.1 software (Applied Biosystems) was used to calculate the cycle threshold $(\mathrm{Ct})$ values.

Controls for both RT and PCR were included in each experiment to ensure target-specific amplification. In addition, we repeated the detection if $\mathrm{Ct} \mathrm{U} 6 \mathrm{did}$ not occur within 32 cycles. The used primers were designed with Gene Runner Software (Hasting Software, Inc., Hasting, NY, USA) based on sequences obtained from GenBank as follows.

\begin{tabular}{ll}
\hline miRNAs & Primer sequence \\
\hline miRNA-205 & Sense primer \\
& 5'-TGCGGCCCAGTGTTTAGACTATC-3' \\
& Antisense primer \\
& 5'-GGTGCACTGGATACGACGAACAGA-3' \\
& Sense primer \\
miRNA-21 & 5'-GCCGCTAGCTTATCAGACTGATGT-3' \\
& Antisense primer \\
& 5'-GTCGTATCCAGTGCAGGGTCCGAG-3' \\
& Sense primer \\
U6 '-GCTTCGGCAGCACATATACTAAAAT-3' & Antisense primer \\
& 5'-CGCTTCACGAATTGCGTGTCAT-3' \\
\end{tabular}




\section{Statistical method}

The Mann-Whitney $U$ test was used for the analyses of the expression of different miRNAs. All statistical analyses were performed using SPSS 23.0 software (SPSS Inc., Chicago, IL, USA). Correlations between quantitative variables were done using Pearson correlation coefficient. Differences were considered significant if $p<0.05$.

\section{Results}

\section{Histological examination of incisional wound}

In group I, the skin section showed dermal edema with loose myxoid degeneration/mucopolysaccharide deposition, together with dermal infiltration by scattered neutrophils and mononuclear inflammatory cells formed mainly of macrophages (Fig. 1a). In group II, almost no inflammatory cells were seen, the edema disappeared and foci of dermal collagen deposition and fibrous tissue formation started (Fig. 1b). In group III, dermal fibrosis increased and hemosiderin deposition was evident by this time (Fig. 1c, Table 1).

\section{Assessment of miRNA expressions}

miRNA-205 and miRNA-21 expressions in group II were significantly higher $(6.02 \pm 1$ and $3.3 \pm .7$, respectively, with $P$ value ${ }^{<} 0.05$ ) than other groups (Fig. 2, Table 2). However, Pearson correlation did not show significant evidence that the increased postmortem duration negatively affected miRNA-205 and miRNA-21 expression.

\section{Discussion}

Trauma is the leading cause of mortality all over the world (Eming et al. 2014). Different histological and molecular changes occur in the incisional wound (Paladini et al. 1996). Forensic scientists could use these changes to evaluate the effect of the time passed since death in the incisional wounds (Gunn et al. 2014; Lv et al. 2014).
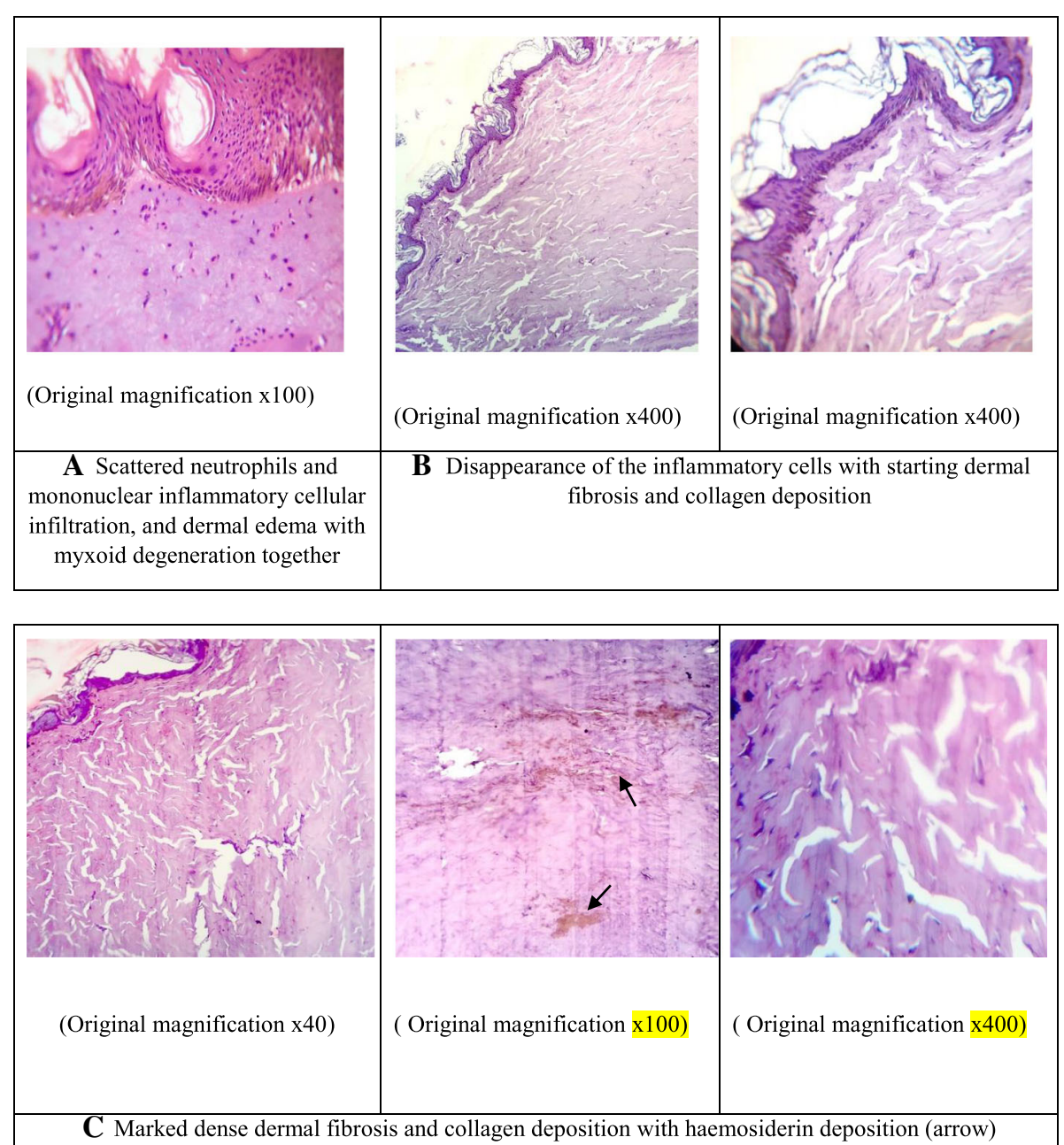

Fig. 1 Photomicrograph of skin specimen in group I (a), group II (b), and group III (c). 
Table 1 Effect of postmortem duration on scoring of skin histopathological picture in rats' incisional wound

\begin{tabular}{|c|c|c|c|}
\hline \multirow[t]{2}{*}{ Parameters } & \multicolumn{3}{|l|}{ Groups } \\
\hline & $\begin{array}{l}\text { Group } 1 \\
\text { (0 postmortem hours) }\end{array}$ & $\begin{array}{l}\text { Group II } \\
\text { (24 postmortem hours) }\end{array}$ & $\begin{array}{l}\text { Group III } \\
\text { (48 postmortem hours) }\end{array}$ \\
\hline Type of inflammatory cells & $\begin{array}{l}\text { Dermal neutrophils and mononuclear cells } \\
\text { (mainly macrophages) }\end{array}$ & Almost no inflammatory cells & Almost no inflammatory cells \\
\hline Edema & $\begin{array}{l}\text { Present with loose myxoid } \\
\text { degeneration/mucopolysaccharide deposition }\end{array}$ & Absent (-) & Absent (-) \\
\hline Fibrous tissue and collagen & Absent & Mild (+) & Marked $(+++)$ \\
\hline Hemosiderin & Absent & Absent & Moderate $(++)$ \\
\hline
\end{tabular}

Absence of histological finding was shown as (-), whereas,+++ , or +++ were considered when there were mild, moderate, or marked levels, respectively, of less than 25,50 , and $75 \%$ affection of total fields examined. Data were collected from skin tissue sections from each animal, three fields/section $(n=3)$

Few researchers had described the forensic aspect of histologic changes of the skin injuries (Siddiqui et al. 2016; Obac et al. 2011; Vinay et al. 2017; Vidinský et al. 2006). Most of these studies were conducted on blunt injuries. No such study was conducted to detect molecular and histological changes in incisional injuries occurred just before death. Therefore, there is a need for such study.

Skin-wound healing starts immediately after mechanical damage. It consists of three phases: inflammation, proliferation, and maturation. Following trauma, there is an overlap in the early inflammation phase and can be recognized as healing signs of wound vitality (Obac et al. 2011).

Vidinský et al. (Vidinský et al. 2006) studied the rats' skin morphology for a period of 7 days after incisional wound. During $24 \mathrm{~h}$ after incision, they noted intense acute inflammatory reaction in the wound area in the form of cellular infiltration, the thickened epidermis at wound margins, and fibrin network filling the incisional space. Starting from day 2 to 7 , they noted healing process in the form of a scab formation, thickened epidermis,

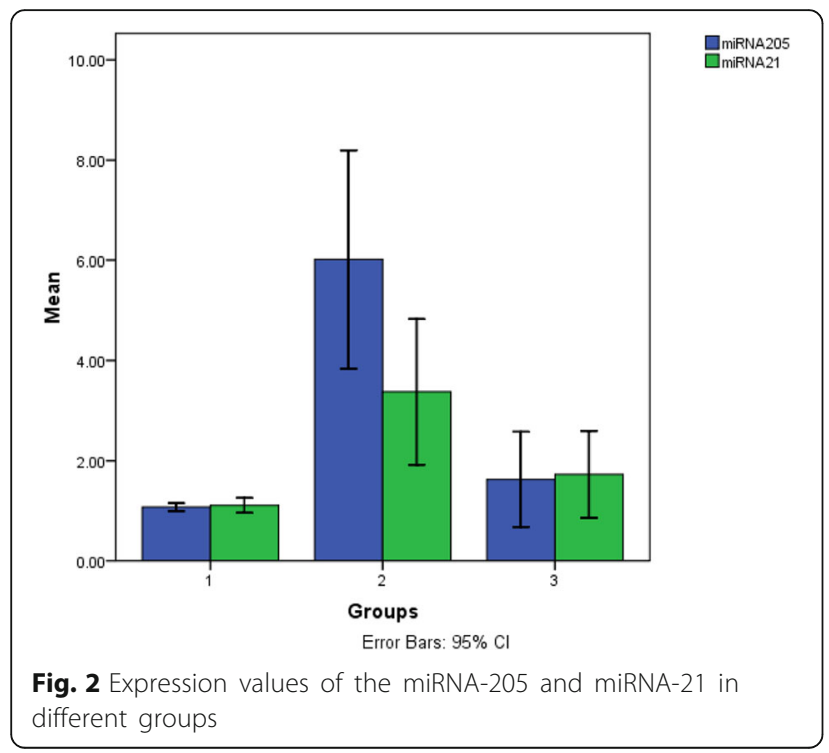

keratinocyte migration, starting re-epithelization, and randomly distributed fibroblasts with no collagen formation.

Similarly, in the our specimens, acute inflammatory cells appeared at wound margin immediately after incision, and with increasing time passed since injury infliction, incisional wounds showed collagen, fibrous, and hemosiderin depositions.

Obac et al. (Obac et al. 2011) evaluated fibrin deposition; a marker of vital reaction, in rats' skin after incisional injuries. The fibrin accumulated at the margins of the ante-mortem incisions ( $1 \mathrm{~h}$ after incision). They concluded that fibrin is feasible to distinguish between ante-mortem and postmortem lesions.

The incisional injury in our study showed significantly higher miRNA-205 and miRNA-21 expressions in group II (24 $\mathrm{h}$ after death) than other groups. Although there is a rapid decrease in miRNA-205 and miRNA-21 expressions in wounded samples, this decrease did not show any statistical significant correlation with postmortem interval. Of note, short duration passed after death did not show a significant increase in mRNA degradation.

A previous study had concluded that miR-205 expression significantly increased in the wound area at $12 \mathrm{~h}$ after wound infliction. Overexpressed miR-205 accelerated the cellular regrowth rate, cellular migration, and cellular proliferation during wound-healing process (Lin et al. 2013).

Table 2 Expression values of the miRNA-205 and miRNA-21 in different groups

\begin{tabular}{lll}
\hline Groups & Parameters & \\
\cline { 2 - 3 } & miR-205 & miR-21 \\
& mean \pm SE & $1.11 \pm .06^{\#}$ \\
\hline Group I & $1.08 \pm .04^{\#}$ & $3.3 \pm .7^{* \$}$ \\
Group II & $6.02 \pm 1^{* \$}$ & $1.7 \pm .4^{\#}$ \\
\hline
\end{tabular}

$S D$ standard error

*Statistically significant compared to corresponding value in group I $(P<0.05)$

"Statistically significant compared to corresponding value in group II $(P<0.05)$

${ }^{\$}$ Statistically significant compared to corresponding value in group III $(P$ $<0.05$ ) 
Long et al. (Long et al. 2018) studied the effect of miR21 on wound healing process in aged mice. They found that miR-21 expression retained a high level in the wound area and allowed better skin repairing capacity. Its level was upregulated at day 7 more than twofold compared to those of day 3. Its dysregulation may contribute to impaired wound repair.

Ludwig et al. (Ludwig et al. 2016) reported that the miR-205 was highly expressed in human skin and can resist environmental variations and PM degradation. This trend could be related to its short length 21-25 bp. Moreover, McClure et al. (McClure et al. 2014) stated that genetic susceptibility and health condition could affect miR-21expression.

Molecular degradation in dead bodies increases, as the postmortem duration increases. Therefore, gene expressions decrease constantly with increasing time after death (Bauer et al. 2003; Sampaio-Silva et al. 2013).

The studied miRNA had been continuously expressed up to $48 \mathrm{~h}$ after death, but at lower level. MicroRNAs can resist ribonuclease degradation due to their being tightly bound to the active RNA-induced silencing complex and play special functions in keeping alive cells after death. Hence, miRNAs can be continuously expressed (Wang et al. 2016).

In this study, we had not demonstrate a significant negative correlation between miRNA expressions and time passed since death. Our results were inconsistent with other studies (Lv et al. 2014; Bauer et al. 2003; SampaioSilva et al. 2013; Wang et al. 2013). Possible reasons for these conflicting results could be related to studied molecular molecule, examined tissue, and chosen postmortem duration (Ali et al. 2017).

Our findings were augmented by the Nagy et al.'s findings (Nagy et al. 2015), who also demonstrated that miRNA expressions in postmortem brain tissue were stable and continuously expressed for up to 4 days.

When the results of the present study were compared with published literature, the histologic pattern and biomolecular findings are more or less similar, but the progression of histologic and bio-molecular changes were different. The reason for this difference is related mainly to the methodological variations; especially the assessment time. The skin samples in our study were examined after death as postmortem samples of perimortal wound. Moreover, the condition of storage environment can greatly affect the speed of bio-molecular and histological changes (Ibrahim 2018).

\section{Conclusion}

Forensic pathologists commonly examine postmortem samples in their practice. Histological examination and reverse transcription polymerase chain reaction are useful techniques to examine these samples.
We found evidence that histological signs of acute inflammation can be detected early in perimortal incisional wounds, starting from time of infliction up to 2 days after death, and can be used as an indicator of wound vitality. However, molecular changes became more evident in determining time passed since death especially at $24 \mathrm{~h}$ duration. Although these histological and molecular findings were encouraging, our study had some limitations; for instance, our attempt in analyzing and correlating the histologic changes had been made in a wide time gap.

More researches are needed into histo- and biomolecular changes of the perimortal wounds within successive shorter intervals from different body sites to augment preliminary results of this study.

\section{Abbreviations}

miRNA: Micro ribonucleic acid; PCR: Polymerase chain reaction

\section{Acknowledgements}

Not applicable

\section{Authors' contributions}

SI prepared the idea, searched the literature, and wrote and revised the manuscript. MA analyzed and interpreted the data and revised the manuscript. $\mathrm{HB}$ collected the data analyzed and revised the manuscript. LR and EA performed the practical part. DA performed histopathological part. All authors read and approved the final manuscript.

\section{Funding}

Not applicable

\section{Availability of data and materials}

All data generated or analyzed during this study are included in this published article.

\section{Ethics approval}

This study was approved by the Ethical Committee of King Saud University, the institutional animal care and use committee, King Saud University.

Consent for publication

Not applicable

\section{Competing interests}

The authors declare that they have no competing interests

\section{Author details}

${ }^{1}$ Forensic medicine and clinical toxicology, Faculty of Medicine, Cairo University, Cairo, Egypt. ${ }^{2}$ Princess Nourah Bint-Abdulrahman University, Riyadh, Saudi Arabia. ${ }^{3}$ Biochemistry, Faculty of Medicine, Cairo University, Cairo, Egypt. ${ }^{4}$ Biochemistry, Faculty of Pharmacy, Ahram Canadian University, 6th of October City, Egypt. ${ }^{5}$ Pathology, Faculty of Medicine, Cairo University, Cairo, Egypt.

Received: 2 April 2019 Accepted: 20 June 2019

Published online: 12 July 2019

\footnotetext{
References

Ali MM, Ibrahim SF, Fayed AA (2017) Using skin gene markers for estimating early postmortem interval at different temperatures. Am J Forens Med Pathol 38(4):323-325

Bauer M, Gramlich I, Polzin S, Patzelt D (2003) Quantification of mRNA degradation as possible indicator of postmortem interval - a pilot study. Legal Med 5(4):220-227

Carthew RW, Sontheimer EJ (2009) Origins and mechanisms of miRNAs and siRNAs. Cell. 136(4):642-655
} 
Da Silva RF, Pereira SDR, Daruge Júnior E, Barcelos RSS, Godinho NMO, Souto R (2016) Genetics and molecular biology: a literature review of forensic dentistry application. Braz J Oral Sci:1254-1259 ISSN 1677-3225

Eming SA, Martin P, Tomic-Canic M (2014) Wound repair and regeneration: mechanisms, signaling, and translation. Sci Translat Med 6(265):265 sr6

Gunn P, Walsh S, Roux C (2014) The nucleic acid revolution continues - will forensic biology become forensic molecular biology? Front Genet 5:44

Ibrahim SF (2018) Human skin identification using specific gene marker at different storage temperatures. Egypt J Forens Sci 8(1):29

Karlsson T (1998) Homicidal and suicidal harp force fatalities in stockholm, sweden: orientation of entrance wounds in stabs gives information in the Classification. Forensic Sci Int 93(1):21-32

Lin D, Halilovic A, Yue P, Bellner L, Wang K, Wang L et al (2013) Inhibition Of Mir205 Impairs the wound-healing process in human corneal epithelial cells by targeting KIR4.1 (KCNJ10). Invest Ophthalmol Vis Sci 54(9):6167-6178

Long S, Zhao N, Ge L, Wang G, Ran X, Wang J et al (2018) Mir-21 ameliorates age-associated skin wound healing defects in mice. J Gene Med 20(6):e3022

Ludwig N, Leidinger P, Becker K, Backes C, Fehlmann T, Pallasch C et al (2016) Distribution of miRNA expression across human tissues. Nucleic Acids Res 44(8):3865-3877

Lv YH, Ma KJ, Zhang H, He M, Zhang P, Shen YW et al (2014) A time course study demonstrating mRNA, microrna, $18 \mathrm{~S}$ rRNA, and U6 snRNA changes to estimate PMI in deceased rat's spleen. J Forens Sci 59(5):1286-1294

McClure C, Brudecki L, Ferguson DA, Yao ZQ, Moorman JP, McCall CE et al (2014) Mir-21 and Mir-181b couple with NFI-A to generate MDSCs and promote immunosuppression in late sepsis. Infect Immun IAl. 01495-14

Nagy C, Maheu M, Lopez JP, Vaillancourt K, Cruceanu C, Gross JA et al (2015) Effects of postmortem interval on biomolecule integrity in the brain. J Neuropathol Exper Neurol 74(5):459-469

Obac A, Carvalho E, Silva P, Fenerich-Verani N, Almeida M (2011) Histological analysis of short-term vital reactions in skin wounds: potential applications in forensic work. Braz J Biol 71(4):1011-1014

Paladini RD, Takahashi K, Bravo NS, Coulombe PA (1996) Onset of reepithelialization after skin injury correlates with a reorganization of keratin filaments in wound edge keratinocytes: defining a potential role for keratin 16. J Cell Biol 132(3):381-397

Sampaio-Silva F, Magalhães T, Carvalho F, Dinis-Oliveira RJ, Silvestre R (2013) Profiling of RNA degradation for estimation of post morterm interval. Plos One. 8(2):e56507

Saukko Pekka KB (2004) Knight's Forensic Pathology Third Edition, 3rd edn. Edward Arnold, London

Siddiqui MAM, Parvathi K, Khan MT, Reddy MN (2016) Histopathological study of blunt force injuries in relation to time since death. J Contemp Med Res 3(9):2780-2783

Vidinský B, Gál P, Toporcer T, Longauer F, Lenhardt L', Bobrov N et al (2006) Histological study of the first seven days of skin wound healing in rats. Acta Veterinaria Brno. 75(2):197-202

Vinay J, Harish S, Mangala GS, Hugar BS (2017) A study on postmortem wound dating by gross and histopathological examination of abrasions. Am J Forensic Med Pathol 38(2):167

Wang H, Mao J, Li Y, Luo H, Wu J, Liao M et al (2013) 5 miRNA expression analyze in post-mortem interval (PMI) within $48 \mathrm{H}$. Forens Sci Int 4(1): e190-e1e1

Wang JL, Wang X, Yang D, Shi WJ (2016) The expression of MicroRNA-155 in plasma and tissue is matched in human laryngeal squamous cell carcinoma. Yonsei Med J 57(2):298-305

Wang T, Feng Y, Sun H, Zhang L, Hao L, Shi C et al (2012) Mir-21 Regulates skin wound healing by targeting multiple aspects of the healing process. Am J Pathol 181(6):1911-1920

Yi R, Poy MN, Stoffel M, Fuchs E (2008) A skin microRNA promotes differentiation by repressing' stemness. Nature. 452(7184):225-229

\section{Publisher's Note}

Springer Nature remains neutral with regard to jurisdictional claims in published maps and institutional affiliations.

\section{Submit your manuscript to a SpringerOpen ${ }^{\circ}$ journal and benefit from:}

- Convenient online submission

- Rigorous peer review

- Open access: articles freely available online

- High visibility within the field

- Retaining the copyright to your article

Submit your next manuscript at $\boldsymbol{\nabla}$ springeropen.com 